\title{
ВПЛИВ ГРЕЛІНУ І ЛЕПТИНУ НА ПОКАЗНИКИ МЕТАБОЛІЧНОГО СИНДРОМУ ЗА УМОВ ВИСОКОКАЛОРІЙНИХ ДІЄТ В ЕКСПЕРИМЕНТІ
}

Вступ. Ожиріння - пусковий механізм розвитку інсулінорезистентності, яка є ключовою ланкою патогенезу метаболічних захворювань.

Мета дослідження - вивчити співвідношення секреції греліну і лептину, показники ліпідного та вуглеводного обміну в щурів на тлі висококалорійних дієт.

методи дослідження. Дослідження проводили на статевозрілих щурах-самцях, які перебували на дієті з високим вмістом фрруктози (1-ша група) та жиру (2-га група). у сироватці піддослідних тварин визначали вміст гормонів греліну та лептину, маркери вуглеводного обміну, ліпідний спектр крові.

Результати й обговорення. У тварин 1-ї та 2-ї груп встановили зменшення рівня греліну на 33,67 i 46,54 \%, лептину - на 52,62 та 68,62 \% відповідно щодо даних в інтактних щурів. За умов навантаження фрруктозою спостерігали розвиток інсулінорезистентності, на що вказувало збільшення вмісту глюкози (на 76,57\%), інсуліну (на 47,96 \%), індексу HOMA-IR (у 2,31 раза) стосовно контролю. Концентрація глікозильованого гемоглобіну в цільній крові зросла у 2 рази щодо даних в інтактних щурів. У тварин на тлі високожирової дієти відзначали однонапрямлені зміни (підвищення концентрації глюкози на 27,69 \%, інсуліну - на 38,47 \% у сироватці крові, глікозильованого гемоглобіну в цільній крові - на 82,05 \% відносно даних в інтактних щурів). Індекс НОМА-IR у тварин на тлі високожирової дієти збільшився на 79,14 \% стосовно контролю. Зміни вуглеводного обміну суттєво вплинули на ліпідний спектр крові, зокрема, підвищився вміст загального холестерину (на 41,66 і 49,24 \%), холестерину ліпопротеїнів низької щільності (на 73,21 та 80,35 \%), тригліцеридів (на 52,38 і 73,81 \%) на тлі зниження вмісту холестерину ліпопротеїнів високої щільності (на 47,96 та 26,54 \%) у тварин з інсулінорезистентністю і ожирінням відповідно. Встановлено тісний кореляційний взаємозв'язок між вмістом греліну і лептину та показниками вуглеводного (концентрацією глюкози, інсуліну, індексом HOMA-IR) і жирового обміну (коефіцієнтом атерогенності, вмістом загального холестерину, тригліцеридів).

Висновки. Перебування тварин на висококалорійній дієті (високовуглеводній чи високожировій) супроводжується розвитком інсулінорезистентності та вторинної дисліпідемії. Концентрація греліну та лептину суттєво впливає на розвиток окремих компонентів метаболічного синдрому.

КЛЮЧОВІ СЛОВА: грелін; лептин; інсулінорезистентність; ожиріння; вуглеводний обмін; ліпідний спектр крові.

ВСТУП. Надмірне споживання висококалорійних продуктів може спричинити розвиток ожиріння та спровокувати появу кардіоваскулярних і гепатобіліарних ризиків з наступним розвитком патологічних змін, зокрема метаболічного синдрому, передіабетичного стану, цукрового діабету 2 типу. Основними проявами порушення обміну речовин при ожирінні є недостатня утилізація глюкози м'язами, гіперглікемія, що призводить до збільшення накопичення жировою тканиною глюкози і перетворення її на резервні ліпіди [1]. Посилення секреції інсуліну та зростання його концентрації у крові зумовлюють перетворення харчової глюкози на жир. Ожиріння, у свою чергу, є однією з основних причин виникнення інсулінорезистентності, особливо за умов (c) Е. М. Цимбала, 2021. перебування на високовуглеводній чи високожировій дієті [2]. Водночас надмірна маса тіла та цукровий діабет 2 типу є вагомими фракторами прогнозування ускладнень від COVID-19 (вищі ризики ушпиталення, інтенсивної терапії, кисневої дотації і летальності).

Важливу роль у збільшенні маси тіла відіграють гормони-регулятори харчової поведінки. На сьогодні актуальним залишається питання щодо вивчення впливу гормону пептидної природи, що синтезується в жировій тканині, - лептину [3]. Основними фрізіологічними еоректами лептину $€$ активація симпатичної нервової системи, що зумовлює підвищення метаболізму жирів та глюкози, участь у регуляції синтезу інсуліну [4]. Обмежене споживання їжі чи голодування призводить до зниження концентрації лептину, а 
переїдання підвищує його рівень. Обернену залежність із жировою масою тіла та концентрацією лептину має гормон грелін, який підвищує апетит, сприяє збільшенню м'язової маси, підвищує концентрацію глюкози у крові [5].

Мета дослідження - вивчити співвідношення секреції греліну і лептину, показники ліпідного та вуглеводного обміну в щурів на тлі висококалорійних дієт.

МЕТОДИ ДОСЛІДЖЕННЯ. Дослідження проводили на статевозрілих щурах-самцях, яких поділили на такі групи: контрольна - інтактні

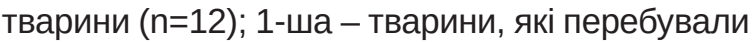
на високовуглеводній дієті (n=12); 2-га - тварини, які перебували на високожировій дієті ( $\mathrm{n=12)}$. Щури контрольної групи перебували на стандартному харчовому раціоні віварію. Тварини 1-ї дослідної групи отримували замість питної води $10 \%$ розчин фрруктози протягом 8-ми тижнів [6]. Щури 2-ї дослідної групи перебували на гіперкалорійній дієті з високим вмістом жирів та холестерину впродовж дослідження (8-ми тижнів) [7].

Вміст лептину і греліну досліджували за допомогою реактивів Rat Lpt (Leptin) ELISA Kit (Elabscience, USA) та Rat GHRL (Ghrelin) ELISA Kit (Elabscience, USA) відповідно на приладі ER-500 Microplate Reader. Зміни вуглеводного обміну характеризували за вмістом інсуліну та глюкози у сироватці крові з наступним обчисленням індексу інсулінорезистентності HOMA-IR (Homeostasis Model Assessment Insulin Resistane), а також визначали рівень глікозильованого гемоглобіну (HbA1c) у цільній крові. Концентрацію глюкози у сироватці крові та вміст НbA1с визначали за допомогою наборів “Реагент" (Дніпро, Україна). Вимірювання проводили на планшетному імуносрерментному аналізаторі STAT FAX 2100 (Китай). Вміст інсуліну досліджували за допомогою реагентів Rat INS (Insulin) ELISA Kit (Elabscience, USA). Ліпідний спектр сироватки крові оцінювали за рівнем у сироватці крові загального холестерину (3ХC), холестерину ліпопротеїнів низької щільності (ХС ЛПНЩ), холестерину ліпопротеїнів високої щільності (XC лПВЩ), тригліцеридів (ТГ) з наступним обчисленням коесріцієнта атерогенності (КА). Для визначення показників ліпідного спектра крові використовували тест-набори "Філісіт-Діагностика" (Дніпро, Україна), вимірювання проводили на спектрофоотометрі LV/VIS ULAB [8].

Утримування, вигодовування та виведення щурів з експерименту відповідали чинним міжнародним вимогам стосовно гуманного ставлення до тварин згідно з Директивою Ради Європи 86/609/EEC (1986) і міжнародними принципами Європейської конвенції про захист хребетних тварин, що використовуються для дослідних та інших наукових цілей (Страсбург, 1986), відповідно до правил Належної лабораторної практики (GLT) і з дотриманням загальних етичних принципів проведення експериментів на тваринах, ухвалених на Інтернаціональному конгресі з біоетики (Київ, 2000), Закону України № 3447-IV “Про захист тварин від жорстокого поводження", загальних етичних принципів експериментів на тваринах, ухвалених на Першому національному конгресі України з біоетики (2001).

Статистичний аналіз даних проводили 3 використанням пакета математичних програм StatisticSoft 7,0. Для кожної з вибірок перевіряли, чи $є$ нормальним розподіл досліджуваного показника, застосовуючи критерії Колмогорова Смірнова, Ліллієсрорса. Оскільки отримані дані відповідали закону Гауса, результати представлено інтервалом $\mathrm{M} \pm \mathrm{m}$. Достовірність різниці даних у вибірках перевіряли за допомогою параметричного t-критерію Стьюдента, наявність кореляційного взаємозв'язку - з використанням коефіцієнта кореляції Пірсона (r). Статистично достовірною вважали різницю при р<0,05.

РЕЗУЛЬТАТИЙОБГОВОРЕННЯ. У РезУЛЬТаТі дослідження спостерігали зниження рівня греліну в сироватці крові піддослідних тварин: у 1-й групі - на 33,67\% $(p<0,05)$, у 2-й - на 46,54 \% $(p<0,05)$ щодо даних контролю (табл. 1). Такі зміни можуть характеризувати достатнє метаболічне і сенсорне насичення щурів, проте можна припустити високу ймовірність розвитку в них метаболічного синдрому.

Варто зазначити, що у сироватці крові тварин 1-ї дослідної групи рівень лептину збільшився на 52,62 \% (p<0,05), 2-ї - на 68,62 \% $(p<0,05)$ щодо даних в інтактних щурів. Такі зміни можуть відображати перерозподіл жирової тканини, низьку фрізичну активність, зменшення витрат енергії. Імовірно, зростання вмісту лептину в сироватці крові пов'язане з накопиченням ліпідів та розвитком інсулінорезистентності [9]. Відомо, що лептин захищає периферичні тканини від накопичення ліпідів, бере участь у збереженні гомеостазу вільних жирних кислот та посилює їх окиснення [10]. Гіперлептинемія може відображати компенсаторну резистентність гіпоталамуса до центральної дії лептину, особливо при ожирінні.

За таких умов у тварин, які перебували на високовуглеводній і високожировій дієтах, виявлено зміни показників вуглеводного обміну (див. табл. 1). Зокрема, у сироватці крові тварин 1-ї дослідної групи вміст глюкози збільшився на 
76,57 \% (p<0,001) щодо даних в інтактних щурів, що свідчило про порушений синтез інсуліну $\beta$-клітинами підшлункової залози. У сироватці крові тварин цієї ж групи рівень інсуліну підвищився стосовно контролю. Такі зміни зумовили зростання індексу НОMA-IR у 2,31 раза $(p<0,001)$ порівняно з аналогічними показниками інтактних щурів. Цей спектр змін підтвердив розвиток у них інсуліноризистентності. У сироватці крові піддослідних тварин, які перебували на високожировій дієті (2-га група), зміни досліджуваних показників були однонапрямленими: збільшився вміст глюкози на 27,69 \% ( $<<0,05)$, інсуліну - на $38,47 \%(p<0,05)$, а також НbA1с у цільній крові на 82,05\% ( $<<0,001)$ порівняно 3 інтактними щурами. Індекс HOMA-IR підвищився на 79,14 \% $(p<0,01)$ щодо контролю. Такі дані свідчать про порушення толерантності до глюкози та вуглеводів у тварин обох дослідних груп незалежно від дієти, що є суттєвим ризиком розвитку метаболічних розладів.

У щурів, які перебували на висококалорійних дієтах, розвивалися зміни показників ліпідного спектра крові. Зокрема, перебування тварин на високовуглеводній та високожировій дієтах супроводжувалось зростанням вмісту ЗХС, відповідно, на 41,66 \% (p<0,001) і 49,24\% $(p<0,01)$ стосовно даних у щурів контрольної групи (табл. 2). У тварин 1-ї дослідної групи встановили збільшення вмісту ХС ЛПНЩ і ТГ на 73,21 \% (p<0,001) та 52,38 \% (p<0,05), у щурів 2-ї дослідної групи - відповідно, на 80,35 \% (p<0,001) i $73,81 \%$ ( $<<0,001)$ щодо даних в інтактних тварин. Підвищення вмісту ТГ у сироватці крові всіх піддослідних щурів може бути тісно пов'язане 3 вивільненням жирних кислот із жирової тканини внаслідок активації ліполізу на тлі інсулінорезистентності [11]. Зниження рівня ХС лПВщ на $47,96 \%(p<0,01)$ і 26,54 \% (p<0,01) у тварин 1-ї та 2-ї дослідних груп може відображати компенсаторну реакцію на збільшення проатерогенних фрракцій холестерину. Привертає увагу суттєве підвищення КА: у 8,29 раза $(p<0,01)$ - у тварин з інсулінорезистентністю, в 5,08 раза $(p<0,001)-$ у щурів з ожирінням щодо даних в інтактних тварин. Отримані зміни ліпідного спектра крові в піддослідних тварин відображають розвиток вторинної дисліпідемії. Водночас достовірних розбіжностей між досліджуваними показниками у щурів 1-ї та 2-ї дослідних груп не було встановлено.

Встановлено кореляційний взаємозв'язок між вмістом греліну та: індексом HOMA-IR - зворотний, середньої сили ( $r=-0,57, p<0,05)$, вмістом інсуліну - зворотний, середньої сили ( $r=-0,62$, $p<0,01)$, ЗХС - зворотний, сильний $(r=-0,86$, $p<0,001)$, ТГ- зворотний, середньої сили $(r=-0,39$, p<0,05); рівнем лептину і концентрацією глюкози - прямий, сильний $(r=0,89, p<0,05)$, інсуліну прямий, середньої сили $(r=0,57, p<0,05)$, КА -

Таблиця 1 - Зміни показників гормонального профілю і вуглеводного обміну в щурів,

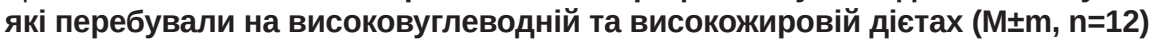

\begin{tabular}{|c|c|c|c|c|c|c|}
\hline Група тварин & $\begin{array}{c}\text { Лептин, } \\
\text { нг/мл }\end{array}$ & $\begin{array}{l}\text { Грелін, } \\
\text { нг/мл }\end{array}$ & $\begin{array}{l}\text { Інсулін, } \\
\text { мкОД/л }\end{array}$ & $\begin{array}{l}\text { Глюкоза, } \\
\text { ммоль/л }\end{array}$ & $\begin{array}{c}\text { Глікозильо- } \\
\text { ваний гемоглобін, } \\
\text { мкмоль } \\
\text { фрруктози/г Нb }\end{array}$ & $\begin{array}{c}\text { Індекс } \\
\text { HOMA-IR }\end{array}$ \\
\hline $\begin{array}{l}\text { Контрольна } \\
\text { (інтактні тварини) }\end{array}$ & $6,50 \pm 1,44$ & $1,01 \pm 0,14$ & $15,18 \pm 2,10$ & $4,91 \pm 0,35$ & $3,12 \pm 0,16$ & $3,26 \pm 0,43$ \\
\hline $\begin{array}{l}\text { 1-ша дослідна } \\
\text { (високовуглеводна дієта) }\end{array}$ & $\begin{array}{c}9,92 \pm 0,55 \\
p<0,05\end{array}$ & $\begin{array}{c}0,67 \pm 0,07 \\
p<0,05\end{array}$ & $\begin{array}{c}22,46 \pm 0,67 \\
p<0,001\end{array}$ & $\begin{array}{c}8,67 \pm 0,64 \\
p<0,001\end{array}$ & $\begin{array}{c}6,25 \pm 0,63 \\
p<0,001\end{array}$ & $\begin{array}{c}7,54 \pm 0,74 \\
p<0,001\end{array}$ \\
\hline $\begin{array}{l}\text { 2-га дослідна } \\
\text { (високожирова дієта) }\end{array}$ & $\begin{array}{c}10,96 \pm 1,09 \\
p<0,05\end{array}$ & $\begin{array}{c}0,54 \pm 0,11 \\
p<0,05\end{array}$ & $\begin{array}{c}21,02 \pm 1,66 \\
p<0,05\end{array}$ & $\begin{array}{c}6,27 \pm 0,37 \\
p<0,05\end{array}$ & $\begin{array}{c}5,68 \pm 0,43 \\
p<0,001\end{array}$ & $\begin{array}{c}5,84 \pm 0,45 \\
p<0,01\end{array}$ \\
\hline
\end{tabular}

Примітка. Тут і в таблиці 2: р - достовірна різниця щодо аналогічних даних у тварин контрольної групи.

Таблиця 2 - Зміна показників ліпідного спектра крові щурів, які перебували

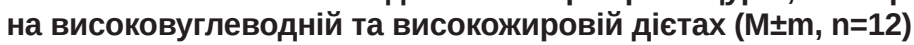

\begin{tabular}{|c|c|c|c|c|c|}
\hline Група тварин & $\begin{array}{c}\text { Загальний } \\
\text { холестерин, } \\
\text { ммоль/л }\end{array}$ & $\begin{array}{c}\text { Холестерин } \\
\text { ліпопротеїнів } \\
\text { низької щільності, } \\
\text { ммоль/л }\end{array}$ & $\begin{array}{c}\text { Холестерин } \\
\text { ліпопротеїнів } \\
\text { високої щільності, } \\
\text { ммоль/л }\end{array}$ & $\begin{array}{c}\text { Тригліцериди, } \\
\text { ммоль/л }\end{array}$ & $\begin{array}{c}\text { Коесріцієнт } \\
\text { атерогенності, } \\
\text { ум. од. }\end{array}$ \\
\hline $\begin{array}{l}\text { Контрольна } \\
\text { (інтактні тварини) }\end{array}$ & $1,32 \pm 0,05$ & $0,56 \pm 0,03$ & $0,98 \pm 0,05$ & $0,42 \pm 0,03$ & $0,34 \pm 0,11$ \\
\hline $\begin{array}{l}\text { 1-ша дослідна } \\
\text { (високовуглеводна } \\
\text { дієта) }\end{array}$ & $\begin{array}{c}1,87 \pm 0,12 \\
p<0,001\end{array}$ & $\begin{array}{c}0,97 \pm 0,09 \\
p<0,001\end{array}$ & $\begin{array}{c}0,51 \pm 0,10 \\
p<0,01\end{array}$ & $\begin{array}{c}0,64 \pm 0,08 \\
p<0,05\end{array}$ & $\begin{array}{c}2,82 \pm 0,81 \\
p<0,01\end{array}$ \\
\hline $\begin{array}{l}\text { 2-га дослідна } \\
\text { (високожирова дієта) }\end{array}$ & $\begin{array}{c}1,97 \pm 0,14 \\
p<0,01\end{array}$ & $\begin{array}{c}1,01 \pm 0,08 \\
p<0,001\end{array}$ & $\begin{array}{c}0,72 \pm 0,04 \\
p<0,01\end{array}$ & $\begin{array}{c}0,73 \pm 0,05 \\
p<0,001\end{array}$ & $\begin{array}{c}1,73 \pm 0,26 \\
p<0,001\end{array}$ \\
\hline
\end{tabular}


прямий, сильний (r=0,86, p<0,05), 3ХС - прямий, сильний $(r=0,77, p<0,05)$, ТГ - прямий, сильний $(r=0,79, p<0,05)$.

ВИСНОВКИ. Таким чином, у щурів, які перебувають на висококалорійній дієті (високовуглеводній або високожировій), порушується вуглеводний обмін, прогресує зниження функції $\beta$-ендокриноцитів та фрормується резистентність до інсуліну. Розвиток вторинної дисліпідемії сигналізує про сутєве зростання кардіоваскулярного ризику за досліджуваних умов. Встановлено тісний кореляційний взаємозв'язок між вмістом греліну і лептину та показниками вуглеводного (концентрацією глюкози, інсуліну, індексом HOMA-IR) і жирового (коефіцієнтом атерогенності, рівнями загального холестерину, трилгліцеридів) обміну.

\section{СПИСОК ЛІТЕРАТУРИ}

1. Антонишин В. І. Взаємозв'язок порушень вуглеводного та ліпідного обміну з рівнем фрактора некрозу пухлин-альфа при експериментальному аліментарному ожирінні / В. І. Антонишин // Мед. та клініч. хімія. - 2015. - 17, № 2. - С. 80-83.

2. Вплив високожирової дієти на розвиток інсулінорезистентності та метаболічного синдрому у щурів / П. К. Цапенко, М. І. Василенко, Р. Б. Алієв [та ін.] // Укр. журн. медицини, біології та спорту. - 2020. - 5, № 3 (25). - С. 441-444.

3. Большова О. В. Вміст греліну та лептину в плазмі крові в дітей та підлітків із диссункцією гіпоталамуса / О. В. Большова, Т. М. Маліновська // Міжнар. ендокринол. журн. - 2018. - 14, № 8. - С. 719-724.

4. Кудрявцев А. А. Роль та місце греліну у патології захворювань органів шлунково-кишкового тракту / А. А. Кудрявцев // Східноєвроп. журн. внутрішньої та сімейної медицини. - 2019. - № 2. - С. 90-98.

5. Корнєєва Е. В. Роль греліну та лептину в регуляції маси тіла у пацієнтів з метаболічним синдромом / Е. В. Корнєєва // Вісн. нових медичних технологій. 2014. - 21, № 1. - С. 36.

6. Шупрович А. А. Порушення обміну сечової кислоти у щурів з експериментальним інсулінорезистентним синдромом, індукованим фруктозою /

\section{REFERENCES}

1. Antonyshyn, V.I. (2015). Vzaiemozviazok porushen vuhlevodnoho ta lipidnoho obminu z rivnem faktora nekrozu pukhlyn-alfa pry eksperymentalnomu alimentarnomu ozhyrinni [Relationship between carbohydrate and lipid metabolism disorders and tumor necrosis factoralpha levels in experimental dietary obesity]. Medychna ta klinichna khimiia - Medical and Clinical Chemistry, 17 (2), 80-83 [in Ukrainian].

2. Tsapenko, P.K., Vasylenko, M.I., Aliyev, R.B., Zavhorodniy, M.O., Kozlovska, M.H., Topchanyuk, L.Ya., et al. (2020). Vplyv vysokozhyrovoi diiety na rozvytok insulinorezystentnosti ta metabolichnoho syndromu u shchuriv [The effect of high-fat diet on the development of insulin resistance and metabolic syndrome in rats]. Ukrainskyi zhurnal medytsyny, biolohii ta sportu Ukrainian Journal of Medicine, Biology and Sport, 5 (3), 441-444 [in Ukrainian].

3. Bolshova, O.V., \& Malinovska, T.M. (2018). Vmist hrelinu ta leptynu $v$ plazmi krovi $v$ ditei ta pidlitkiv iz dysfunktsiieiu hipotalamusa [Plasma ghrelin and leptin
А. А. Шупрович, Н. М. Гуріна, О. В. Корпачева-Зінич // Фізіол. журн. - 2011. - 57, № 1. - С. 72-81.

7. Півторак К. В. Субмікроскопічний стан печінки при корекції стеатозу гепатопротектором амінокислотного походження / К. В. Півторак // Вісн. проблем біології і медицини. - 2015. - 2, № 123. - С. 310-313.

8. Воронич-Семченко Н. М. Кореляція тиреоїдного статусу з показниками ліпідного обміну та рівнем психосрізіологічного розвитку дітей із латентним гіпотиреозом / Н. М. Воронич-Семченко // Фізіол. журн. 2008. - 54, № 3. - С. 57-64.

9. Лептин та його роль у внутрішній патології / О. М. Радченко, О. Р. Слаба, Н. С. Бек, Л. М. Радченко // Мед. гідрологія та реабілітація. -2011. - 9, № 4. C. 101-119.

10. Sato A. Leptin does not influence surfactant synthesis in fetal sheep and mice lungs / A. Sato, A. Schehr, M. Ikegami // Am. J. Physiol. Lung Cell Mol. Physiol. - 2011. - 300 (3). - P. 498-505.

11. Взаємовплив стану ліпідного спектру крові та вмісту адипокінів на клінічний перебіг неалкогольної жирової хвороби печінки за наявності коморбідної хронічної хвороби нирок / А. А. Антонів, О. С. Хухліна, 3. Я. Коцюбійчук [та ін.] // Укр. журн. медицини, біології та спорту. - 2021. - 6, № 3 (31). - С. 148-153.

levels in children and adolescents with hypothalamic dysfunction]. Mizhnarodnyi endokrynolohichnyi zhurnal International Journal of Endocrinology, 14 (8), 719-724 [in Ukrainian].

4. Kudryavtsev, A.A. (2019). Rol ta mistse hrelinu u patolohii zakhvoriuvan orhaniv shlunkovo-kyshkovoho traktu [The role and place of ghrelin in the pathology of diseases of the gastrointestinal tract]. Skhidnoievropeiskyi zhurnal vnutrishnoi ta simenoi medytsyny - Shidnoevropeiskyi zurnal vnutrisnoi ta simeinoi medytsyny, 2, 90-98 [in Ukrainian].

5. Kornyeyeva, E.V. (2014). Rol hrelinu ta leptynu v rehuliatsii masy tila u patsiientiv z metabolichnym syndromom [The role of ghrelin and leptin in the regulation of body weight in patients with metabolic syndrome]. Visnyk novykh medychnykh tekhnolohii-Bulletin of New Medical Technologies, 21 (1), 36 [in Ukrainian].

6. Shuprovych, A.A., Hurina, N.M., \& KorpachevaZinych, O.V. (2011). Porushennia obminu sechovoi kysloty u shchuriv z eksperymentalnym insulinorezys- 
tentnym syndromom, indukovanym fruktozoiu [Disorders of uric acid metabolism in rats with experimental insulinresistant syndrome induced by fructose]. Fiziolohichnyi zhurnal - Physiological Journal, 57 (1), 72-81 [in Ukrainian].

7. Pivtorak, K.V. (2015). Submikroskopichnyi stan pechinky pry korektsii steatozu hepatoprotektorom aminokyslotnoho pokhodzhennia [Submicroscopic condition of the liver in the correction of steatosis with hepatoprotector of amino acid origin]. Visnyk problem biolohii i medytsyny - Bulletin of Problems of Biology and Medicine, 2 (123), 310-313 [in Ukrainian].

8. Voronych-Semchenko, N.M. (2008). Koreliatsiia tyreoyidnoho statusu z pokaznykamy lipidnoho obminu ta rivnem psykhofiziolohichnoho rozvytku ditei iz latentnym hipotyreozom [Correlation of thyroid status with indicators of lipid metabolism and the level of psychophysiological development of children with latent hypothyroidism]. Fiziolohichnyi zhurnal - Physiological Journal, 54 (3), 57-64 [in Ukrainian].
9. Radchenko, O.M., Slaba, O.R., Bek, N.S., \& Radchenko, L.M. (2011). Leptyn ta yoho rol u vnutrishnii patolohii [Leptin and its role in internal pathology]. Medychna hidrolohiia ta reabilitatsiia - Medical Hydrology and Rehabilitation, 9 (4), 101-109 [in Ukrainian].

10. Sato, A., Schehr, A., \& Ikegami, M. (2011). Leptin does not influence surfactant synthesis in fetal sheep and mice lungs. Am. J. Physiol.Lung Cell Mol. Physiol., 300 (3), 498-505.

11. Antoniv, A.A, Khukhlina, O.S., Kotsyubiychuk, Z.Ya., Vivsyannyk, V.V., Kanovska, L.V., \& Mandryk, O.Ye. (2021). Vzaiemovplyv stanu lipidnoho spektru krovi ta vmistu adypokiniv na klinichnyi perebih nealkoholnoi zhyrovoi khvoroby pechinky za naiavnosti komorbidnoi khronichnoi khvoroby nyrok [Interaction of the state of the blood lipid spectrum and the content of adipokines on the clinical course of non-alcoholic fatty liver disease in the presence of comorbid chronic kidney disease]. Ukrainskyi zhurnal medytsyny, biolohii ta sportu Ukrainian Journal of Medicine, Biology and Sport, 6 (3), 148-153 [in Ukrainian].

E. M. Tsymbala

\section{THE INFLUENCE OF GHRELIN AND LEPTIN ON METABOLIC SYNDROME INDICATORS UNDER CONDITIONS OF HIGH-CALORIE DIETS IN THE EXPERIMENT}

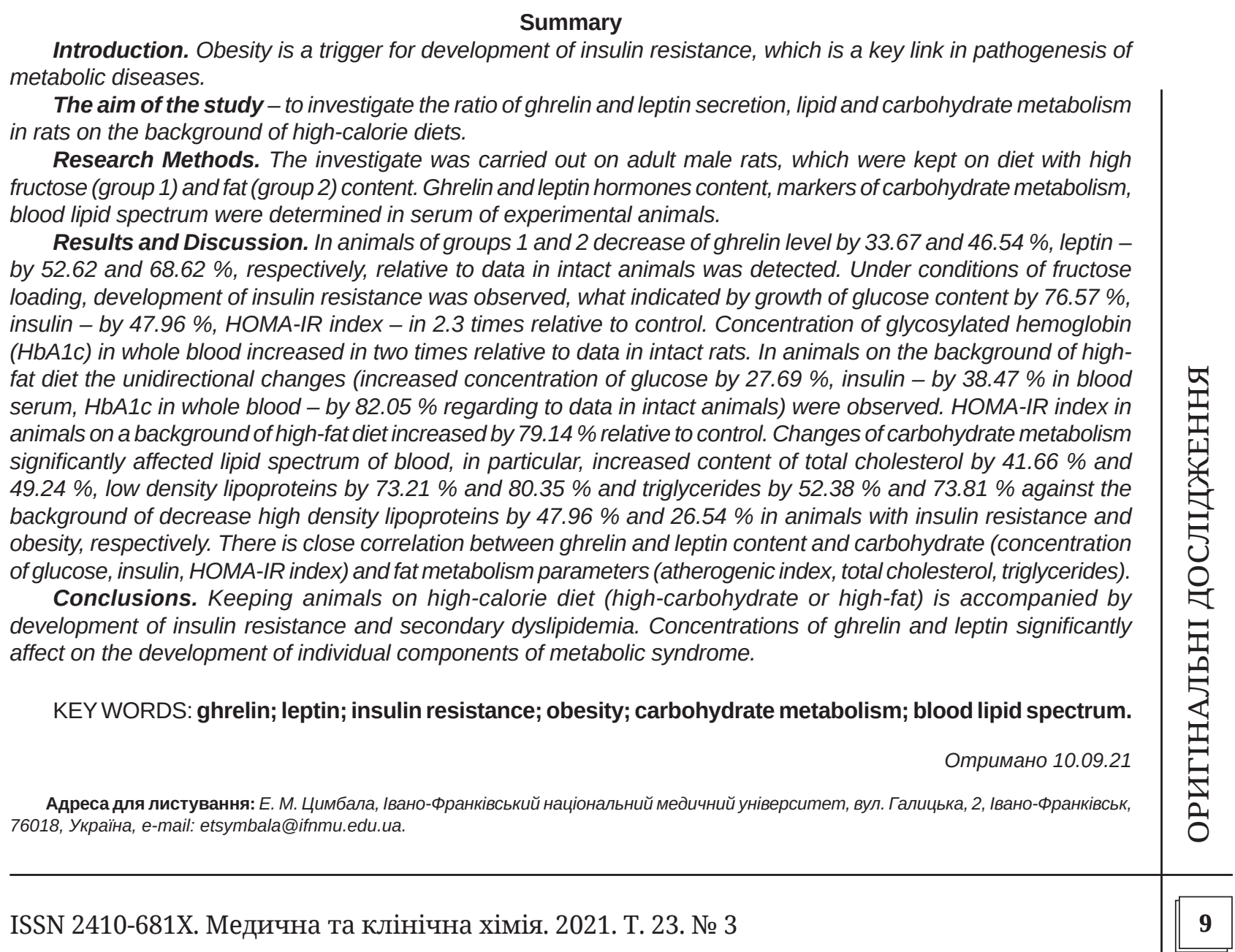

